\title{
Building Consumers' Awareness on Local Creative Industry Products
}

\author{
Risna Kartika ${ }^{1, *}$ Faizal Haris Eko Prabowo ${ }^{1}$ Marlina Nur Lestari ${ }^{1}$ Nandang Fauzi \\ $\operatorname{Rahman}^{1}$
}

\author{
${ }^{1}$ Galuh Univeristy, Indonesia \\ *Corresponding author. Email: risnakartika@gmail.com
}

\begin{abstract}
Creative industry products in Indonesia, especially Mendong from Tasikmalaya are in demand by foreign consumers, especially Korea, Malaysia, India, and the United Kingdom. However, local consumers are not that interested in the products, thus some Mendong sellers shut down their business. Therefore, this study aimed at building local consumers' awareness of Mendong crafts from Tasikmalaya. This study employed a survey method by using qualitative approach to collect the data. It involved consumers of Mendong crafts products in Tasikmalaya. The data analysis technique used was induction. The result of this study shown that consumers' awareness can be built by making changes in their perceptions. All respondents knew about Mendong crafts but they didn't know about the diversity of the products, doubted the product quality, didn't know where to buy them, and some respondents bought them only for souvenirs. Consumers were less informed about Mendong crafts, thus, the marketing needed to be intensified by providing moral information about the variety of Mendong crafts, and an encouragement to buy and use Mendong crafts as local products need to be preserved. Information about Mendong crafts can be delivered to the consumers in the form of advertisement, publicity, e-commerce as well as taking part in exhibitions.
\end{abstract}

Keywords: Consumers' Awareness, Perceptions, Mendong Craft, Creative Industry, Tasikmalaya.

\section{INTRODUCTION}

The global economy is currently undergoing major changes, comparable to the emergence of the first, second and third industrial revolutions, now we have entered the stage of the subsequent industrial revolution which is popularly called the Industrial Revolution 4.0. The basic principle of the industrial revolution 4.0 is the incorporation of machines, workflows, and systems, by applying intelligent networks along the chain and production processes to control each other independently [1]. Industry 4.0 has introduced flexible mass production technology [2]. The digital revolution and the era of technological disruption are other terms of industry 4.0. It is called the digital revolution because of the proliferation of computers and the automation of records in all fields. Industry 4.0 is said to be an era of technological disruption because automation and connectivity in a field will make the movement of the industrial world and work competition not linear. One of the unique characteristics of industry 4.0 is the application of artificial intelligence [3]. The difference between the 4th industrial revolution and the previous industrial revolution is first, innovation can be developed and spread much faster than before, with this speed a breakthrough occurred in the current era, on an exponential scale, not on a linear scale. Second, the decline in marginal production costs and the emergence of a platform that unites and concentrates several scientific fields that are proven to increase the yield or output of work. And third, this revolution is related to a global scale, certainly will have a big influence on all countries in the world, because the scope of this transformation occurs in every industrial sector and can have a comprehensive impact [4].

The development of the creative industry sector influences development in European, American and Asian countries, each country builds the potential of the creative industry with the country's capabilities and wisdom, the UK builds its creative industry through the Department of Culture, Media and Sports (DCMS), New Zealand through New Zealand Trade and Enterprise (NZTE), Singapore through the Ministry of Information, Communications and Arts (MICA), and Malaysia through the Malaysia Design and Innovation Center (MDIC) has created new creative cities and has been at the forefront of creative industry contributions. In several 
countries, the creative industry can drive the economy and create jobs and also create business opportunities [5].

The potential in the creative industry in Indonesia is still wide open, given the rich and varied culture and traditions in Indonesia that can continue to be developed, provided that they have high creativity because creative industries are business activities that focus on creation and innovation [6]. The creative industry has 16 sectors, namely applications and game developers, architecture, visual communication design, product design, fashion, animation \& video films, photography, crafts, culinary, music, publishing, advertising, performing arts, fine arts, and television \& radio [7]. The city of Tasikmalaya is one of the cities that has a lot of creative industry, one of them is the Tasikmalaya Mendong Handicraft. Mendong is one of the plants that grow in the swamp, about $100 \mathrm{~cm}$ in length, before it is used as the basic ingredient in making the work, it will first be dried in the sun. The business groups of Tasikmalaya Mendong strongly upholds the tradition of the ancestors that previously Tasikmalaya was a good producer of Mendong plants. Various products produced include mats, multipurpose boxes, wallets, jars, bags, baskets, and others. The center for Mendong business crafts in Tasikmalaya City is in Purbaratu District, Cibeureum, Indihiang, and Tamansari.

In the past 4 years, the turnover of Mendong handicrafts has fallen by $50 \%$, one of the causes was Mendong raw materials were difficult to find so the couldn't the production plans meet production plans [8]. Other constraints faced by the Mendong creative industry include the paradigm of different local consumers and foreigners, sometimes our society tends to choose long-lasting items without questioning as the basic material, they are plastic oriented, all of which must be durable, while foreign consumers look more at goods with materials that can be recycled and tend to dislike plastic waste. Moreover, public awareness in buying local products is still weak, even though domestically-made goods have been widely appreciated by the global market, sometimes local consumers prefer to buy imported products, this is an obstacle for Mendong craftsmen to market their products in their own country. Besides, in terms of the human resources of craftsmen, on average they have entered the non-productive age, of course, their creativity is limited [9]. Based on the observations, few owners of the Mendong handicraft business closed their businesses, the crafts men who initially worked as Mendong weavers chose to turn professions into convection. This potential creative industry certainly has many hopes to survive even to accelerate in local and global markets especially with the challenges and opportunities in the era of industrial revolution 4.0 .

Consumer awareness needs to be built to arouse consumers in the need to preserve and support local products by buying and using them, especially Mendong crafts. Consumer awareness is learning how individuals, groups or organizations choose, buy, use products, services, ideas, or experiences to meet their needs. It can also be said that consumer awareness is The potential concumers' understanding to receive a product. This is related to consumer knowledge of the product [10].

There are several previous studies that examined various creative industry problems, one of them was done to address supply chain management both upstream, internal and downstream in food MSMEs and modes to improve product quality [11], strategies to build brand awareness in the creative fashion industry to raise awareness of the local community [12], the role of the national creative industry on labor, value added and productivity of Indonesian labor [12], the development of the MSME brand strategy which is one solution to survive amid global competition [13], technology contribution for the productivity of creative industries in West Java [14], factors that have a significant influence on the development of the fashion creative industry in West Java include the ability of innovation, knowledge of trends, ability to adapt to trends, experience in fashion business and strong intuition [15], put forward digital marketing in building brand awareness in an effort to inform, persuade and remind the public about the existence of the KIRBI creative industry as one of the SMEs making knitted clothing [16], Consumers' awareness is influenced by various aspects including brand exposure, customer engagement and electronic word of mouth on Uniqlo products [10], creative industries in Lithuania and Estonia are influenced by personal expenses which are sometimes not separate from corporate expenses and creativity that must be developed again [17]. So that the difference in this research with previous research is to find out ways to build consumer awareness to want to buy and use the local creative industrial products with indicators of consumer awareness using only consumer perceptions, because consumer perceptions are important factors starting from choosing, interpreting a product up to the product has its meaning for consumers that will build consumer awareness of certain products.

In this study, researchers will identify efforts that can build consumers' awareness about the Mendong craft products from Tasikmalaya to be able to compete in the 4.0 Industrial Revolution. Based on the background above, this study takes the title "Building Consumers' Awareness On Local Creative Industry Products Facing Industrial Revolution 4.0". The body text starts with a standard first-level heading like INTRODUCTION or any other heading suitable to the content and context. First level headings are in all caps. Copy the content and replace it for other first-level headings in remaining text. Reference citations should be within square bracket [1]. Headings should always be followed by text.

This template, modified in MS Word 2007 and saved as a "Word 97-2003 Document" for the PC, provides authors with most of the formatting specifications needed for preparing electronic versions of their papers. All standard paper components have been specified for three reasons: (1) ease of use when formatting individual papers, (2) automatic compliance to electronic requirements that facilitate the concurrent or later production of electronic products, and (3) conformity of style through out a conference proceedings. 


\section{LITERATURE REVIEW}

Consumer awareness has a broad scope, so there are many differences to determine indicators in consumer awareness, including product knowledge, bargain hunting, general consumer knowledge, price consciousness, and information search [18]. Furthermore, consumer awareness has a definition of social value related to behavior that leads to personal perception [19]. Or consumer awareness that is associated with the surrounding environment that relates to the presence of other people, situations, and events that have an impact on purchasing actions [20]. One of the previous studies that examined various issues of creative industries and consumer awareness, was to increase consumer awareness to consume eco-friendly items marked with eco-labels by utilizing mass media; environmental education; always disseminate to the public about environmental issues [21].

Awareness is the first stage in the process of adoption of consumer behavior in consuming local fruits with indicators of various indicators, including the first is knowledge both from the level of education, economic conditions, sources of information and previous experience. Second, the attitude that is related to acceptance, response, respect, and responsibility. The last is actions related to the adoption of behavior [22]. This study uses one indicator of consumer awareness, namely changes in perception, perception is a psychological process starting from the activity of choosing and interpreting so that consumers can give meaning to an object. The perception process begins with the presence of stimuli that affect the five senses and are referred to as sensations [10]. Consumer perceptions are the indicators to build consumer awareness to buy and use the local creative industrial products, because consumer perceptions are important factors starting from choosing, interpreting a product up to the product has its meaning for consumers that will build consumer awareness of certain products.

\section{METHODOLOGY}

This study used a survey method with a qualitative approach, because the purpose of the survey was to describe the characteristics of a large number of populations, both concerning attitudes, behavior, or social phenomena, so that the data used were primary data because data were obtained directly from data sources [23]. The subjects in the study were consumers of Mendong craft products. This research was located in the center of the creative industry of Mendong crafts Purbaratu sub-district, Tasikmalaya. While the objective of this research is to build consumers' awareness to buy and use products from the creative industry of Mendong craft Tasikmalaya.

The population is all individuals who are the target of research, while the samples are part represent the population. The population in this study were 889 consumers, and the samples were 89 people [23]. The sampling technique used was snowballing sampling with a sampling of initially chosen two or three people and then process based on the information provided by previous respondents. Usually, sampling starts from respondents who are known by the researcher, then process based on the information provided by previous respondents and so on [23].

The data analysis technique used an induction through three stages, namely data reduction, data presentation, and concluding [24]. Data reduction, began with collecting interview results and related documentation. The data that the researcher had collected were chosen based on the needs and suitability of the research so that the data that were not needed were sorted and discarded. The next stage was a simplification of data from research results through coding so that the data were easily understood, presented, summarized in the form of data reduction tables to facilitate the conclusion. The second stage that was carried out by categorizing and compiling a collection of information data to facilitate the conclusion and take action. The presentation of the data used in this qualitative research was a text in the form of brief descriptions, charts, tables, correlations between categories, and flowcharts that are easy to understand, and the last was drawing conclusion to find out how to build consumers' awareness of the creative industrial products of Mendong craft from Tasikmalaya. The stages of the research were problem identification, library study, making interview questions, collecting data with interviews (recording interviews), checking data (editing), coding data (encoding), data entry, processing data and finally interpreting the result.

\section{RESULT AND DISCUSSION}

Consumers' awareness is an understanding held by potential consumers to receive a product. This is based on consumers' perceptions. Perceptions are psychological processes starting from the activity of choosing, organizing, and interpreting so that consumers can give meaning to an object. The perception process begins with the information given (K, Arifin \& Mawardi, 2015). This is related to consumers' knowledge of product information. Based on the results of the interview with the respondents, all respondents knew about Mendong craft products. The respondents understood that Mendong craft products were made from Mendong grass, but some respondents only knew that the product was in the form of mats, because in the past, initially the production of Mendong wicker was only a mat that was used for everyday needs down with the presence of plastic, rubber or fur-based mat products. Even so with the development of technology and market demand, Mendong's craft products have been very varied, ranging from all sizes of wallets which function as clutches or used for storing makeup and cellphones. Mendong is also made into tissue boxes, hats that can be used for traveling or just relaxing, handbags of various sizes and motives, slings bags, sandals, boxes that can be used as a containers to store goods, decorations, and other products. 
Some respondents said that Mendong craft products are indeed quite good, but they doubted the product quality. Some of them prioritized the reliability and the durability of the product than the attractive design. They believed that products with Mendong as the basic material will be easily damaged if exposed to water or used continuously. Actually, Mendong craft products are quite durable if proper maintenance is carried out. The maintenance of Mendong products is easy. However, the respondents realized that Mendong crafts do offer a uniqueness that is not owned by other basic products.

Some respondents purchased this Mendong craft products. But the reason of purchasing this Mendong crafts product was not to be used or for personal use, but only for souvenirs for other people. This shows that the awareness to use and preserve local products, especially Mendong craft product is still considered low. Some of them didn't know where they can buy the Mendong craft products. The little information received by local consumers regarding the variety of Mendong products had caused the little demand for the products from local consumers so that most of Mendong handicraft products only become export commodities.

Therefore, to increase consumer awareness of Mendong handicraft products, marketing needs to be intensified by providing information on the advantages of Mendong woven products, ranging from environmentally friendly materials so as not to produce waste for the environment, and color choices that suit various types. The price offered is affordable from Rp. 25,000 - up to Rp. 300,000, - adjusted for the size and complexity of the design. This Mendong craft product has a long durability with fairly easy maintenance. If it is used for a long period of time, this Mendong fiber will not cause mold.

The information provided can be in the form of advertisements through online media, such as the use of social media especially Facebook, Twitter, and Instagram. This needs celebrities as the brand ambassadors to advertise these unique Mendong woven products from Tasikmalaya. Of Course this requires participation and support from the government local, regional and central to be able to introduce and change consumer perceptions of this Mendong craft products. Publicity is also deemed necessary, namely reporting and reporting on Mendong woven products. Publicity is a tool that can form consumer opinion quickly, so it is often referred to as an effort to socialize or socialize a product. This publicity can be done by the entrepreneurs themselves or from the government or related agencies.

The use of other technologies is by using e-commerce as an MSME marketplace where promotion is easy and inexpensive as a place to sell Mendong woven products. One government program that has been prepared is to provide strategic direction and guidance in accelerating the implementation of e-commerce. It is hoped that this step can be used by SMEs to develop a digital economy in Indonesia. This is one of the opportunities to introduce and facilitate consumer access to be able to dig up information, choose, and compare craft products that they need and want. Therefore, Mendong products are not only bought for souvenirs but can be used with confidence by consumers. Also introducing local products to the wider community can be done by holding regular exhibitions, not only for an annual period, it can be held in a span of 6,3 or even once a month, this effort needs to be carried out to arouse community awareness of the existence of local products in particular Mendong craft products, like those of other creative industries, such as culinary.

\section{CONCLUSION AND RECOMMENDATIONS}

Creative industry is one of the industries that support the economy in various countries so that it influences development including in European, American, and Asian countries. Each country builds the potential of creative industry with the ability and wisdom of the country, as well as Indonesia. One of the creative industries in Tasikmalaya is Mendong plait located in Purbaratu District. Most respondents know about Mendong crafts, but not all know that Mendong woven crafts have many product diversities and some respondents still doubt the durability and reliability of products made from Mendong. To increase consumer awareness of Mendong handicraft products, marketing needs to be intensified by providing moral information and messages about the various advantages of Mendong woven products.

\section{ACKNOWLEDGMENTS}

I would like to express my special thanks of gratitude to Fakultas Ekonomi Universitas Galuh and Universitas Muhammadiyah Yogyakarta for the opportunity to do this wonderful project on the topic Building Consumers' Awareness on Local Creative Industry Products.

\section{REFERENCES}

[1] Lifter, M., \& Tschiesner, A, "The Internet of Things and the Future of Manufacturing".2013. McKinsey \& Company.

[2] Kagermann, H., Wahlster, W., \& Helbig, J. “ Recommendations for Implementing the Strategic Initiative Industrie 4.0. Industrie 4.0" 2013. Working Group, Germany, download on $15^{\text {th }}$ January 2019.

[3] Tjandrawinata, R. R. “ Industri 4 . 0 : Revolusi Industri Abad Ini dan Pengaruhnya pada Bidang Kesehatan dan Bioteknologi" Medicinus, Dexa Laboratories of Biomolecular Sciences (DLBS), 2016. 29(1), 31-39.

[4] World Economic Forum. 2016. Peluang dan Tantangan Era Revolusi Industri 4.0. Retrieved January 15, 2019, from http://aceh.tribunnews.com/2018/11/27/peluangdan-tantangan-era-revolusi-industri-40?page $=2$.

[5] Kamil, A. "Industri Kreatif Indonesia: Pendekatan Analisis Kinerja Industri”.2015. Media Trend, 10(2), 207-225. 
[6] Saedah, E. Kementrian Perindustrian Republik Indonesia: Industri, 2015. Kreatif Masih Potensial, 20.1Retrieved January 12, 2015, from http://www.kemenperin.go.id/artikel/4060/IndustriKreatif-Masih-Potensial

[7] Bekraf. Subsektor Industri Kreatif. 2019. Retrieved January $\quad 16 \quad 2019, \quad$ from www.bekraf.go.id/berita/indeks/11.

[8] Latief, A. AyoBandung : Omzet Pengrajin Mendong Tasik Turun 50\%. 2017. Retrieved January 15, 2019, from

https://www.ayobandung.com/read/2017/01/18/15299/o mzet-pengrajin-mendong-tasik-merosot-50.

[9] Barnas, AAnyaman Mendong Buatan Tasik, Dikenal Hingga Mancanegara. 2016. Retrieved January 15, 2019 from https://www.cendananews.com/2016/04/anyamanmendong-buatan-tasik-dikenal-hinggamancanegara.html.

[10] K, I. D., Arifin, Z., \& Mawardi, K. M. “ Pengaruh Pemasaran Melalui Media Sosial Terhadap Kesadaran Konsumen pada Produk Internasional( Studi pada Pengguna Produk Uniqlo di Indonesia )". 2015. Jurnal Administrasi Bisnis (JAB), 24(1), 1-9.

[11] Tejaningrum, A., Azis, A. M., \& Irjayanti, M. "Mapping the Supply Chain Issues SMEs and Impact for Quality Products". 2016. Journal Management Studies, 4(1), 915. https://doi.org/10.17265/2328-2185/2016.01.002

[12] Roisah, R., Hakim, L., \& Mukminin, A.”Strategi Membangun Brand Awareness Pada Usaha Mikro Kecil Menengah". 2018. Jurnal ABDIMAS BSI, 1(2), 340347.

[13] Sudarwati, Y., \& Satya, V. E."Strategi pengembangan merek usaha mikro, kecil, dan menengah. Jurnal Ekonomi Dan Kebijakan Publik”. 2013. 4(1), 89-101.

[14] Irjayanti, M., Azis, A. M., \& Juariah, R. "Penerapan Teknologi untuk Meningkatkan Produktivitas Usaha Kecil Menengah (Preliminary Study pada Industri Kreatif Usaha Kecil dan Menengah di Jawa Barat)".2016. STIE Ekuitas Bandung, Indon. Banking and Management Review STIE Ekuitas, 5(1), 619-631.
[15] Irjayanti, M., \& Azis, A. M. "Key Success Factors (KSF) of Small Medium Enterprises (SMEs) in Creative Industry". 2015. Banking and Management Review STIE Ekuitas, 5(2), 522-528.

[16] Oktaviani, F., \& Rustandi, D. "Implementasi Digital Marketing dalam Membangun Brand Awareness". 2018.PRofesi Humas, 3(1), 1-20.

[17] Martinaityte, E. and R. K. "The Factors of Creative Industries Development in Nowadays Stage".2018. Economic and Sociology, 8(1), 56-71. https://doi.org/10.14254/2071.

[18]Farzin, M. \& Asl, A.M.” The Effect Of Consumer Awareness On Consumer Etnocentrism and Loyalty Regards To The Functions Of International Brands". 2016. International Journal of Life Science and Pharma Research 2(1):102-14.

[19] Saha, A. \& Kuruppuge, R., H. "Determinants of Consumer Awareness of Green Products : A Study of Customers of Super Markets." 2016. Mediterranean Journal of Social Sciences 7(November).

[20] Ishak, S. \& Zabil, N. F. M. "Impact of Consumer Awareness and Knowledge to Consumer Effective Behavior”. 2012. Asian Social Science 8(6).

[21] Handayani, N. U., Suliantoro, H., \& Ansari, S. D. "Faktor Penentu Kesadaran Konsumen Dalam Pembelian Produk Kertas Bertanda Eco-Label" .2018. Jurnal Ilmiah Manajemen, 8(3), 477-503.

[22] Kurniyanti, N., Rochaeni, S., \& Ichdayati, L. I. "Pengaruh Kesadaran, Persepsi dan Preferensi Konsumen Terhadap Perilaku Konsumen Dalam Mengkonsumsi Buah Lokal Studi Kasus Kawasan Industri Di Jakarta Utara”. 2016. Jurnal Agribisnis, (10), 47-66

[23] Purwanto, E.A., \& Sulistyastuti, D,R., "Metode Penelitian Kuantitatif'. 2011. Yogyakarta: Gava Media.

[24] Hedynata, M. L., \& Radianto, W. E. D. Strategi Promosi Dalam Meningkatkan Penjualan Luscious Chocolate Potato Snack. 2016. PERFORMA: Jurnal Manajemen Dan Start-Up Bisnis, 1(April). 